\title{
Interactive comment on "AMM15: A new high resolution NEMO configuration for operational simulation of the European North West Shelf" by Jennifer A. Graham et al.
}

Jennifer A. Graham et al.

jennifer.graham@metoffice.gov.uk

Received and published: 1 December 2017

The comment was uploaded in the form of a supplement:

https://www.geosci-model-dev-discuss.net/gmd-2017-127/gmd-2017-127-AC1-

supplement.pdf

Interactive comment on Geosci. Model Dev. Discuss., https://doi.org/10.5194/gmd-2017-127, 2017. 